\title{
COMPARISONS OF CATTLE GRAZING AND SHEEP GRAZING
}

\author{
C. C. BoswelL \\ Invermay A gricultural Research Centre, MAF, Mosgiel
}

\section{Abstract}

Controversy has surrounded the possible differences in pasture production which result from grazing by cattle or sheep. Experiments conducted over the 1972-76 period show that pasture production under grazing by sheep is greater than under grazing by cattle under similar intensive managements. A change from sheep grazing to cattle grazing can cause a rapid deterioration in pasture production, while the change in grazing from cattle to shoep brought a slower improvement in pasture production. Cattle grazing restricted the production of the ryegrass componen! of the pastures in the five management systems considered.

\section{INTRODUCTION}

THERE are differences in the effects of different animals on pasture production. This was recognized in two papers presented at the 1970 Conference of the N.Z. Grassland Association. Joyce (1970) reported that his cattle farmlet pastures at Ruakura produced more dry matter (DM) than his sheep farmlet pastures, while Monteath (1970) considered the reverse was true at Invermay. Joyce showed that cattle farmlet pastures produced $8 \%$ more DM than his ewe and lamb farmlets and $22.5 \%$ more than his wether farmlets, while Monteath ef al. (1977) have recently reported that pasture production from ewe and lamb farmlets may be $28 \%$ more than from beef cattle farmlets over a fouryear period.

Joyce's findings were more in agreement with commonly held opinion than those of Monteath. It was assumed that lax grazing and long periods of regrowth in cattle management systems allowed cattle pastures to be close to an optimal leaf area index for a large proportion of the regrowth period. This would improve cattle pasture production relative to the closely and more frequently grazed sheep pastures. Joyce could further argue that his pasture measurement technique provided a good estimate of actual pasture production while Monteath, who measured regrowth from a pre-trimmed area over a period of about four weeks, could claim that he measured the potential production under the two types of animals rather than actual production. 
The less conventional results of Monteath have been discussed by Monteath et al. (1977). Some of their findings are summarized in Table 1 and Figs. 1, 2, and 3 which show total DM from cattle and sheep pastures and individual species' contributions to the DM, respectively, over the four years of the experiment. It can be seen that during the four years differences in pasture composition developed. Thus Lolium perenne L. 'Grasslands Ruanui' perennial ryegrass remained dominant in sheep pastures but in cattle pastures Dactylis glomerata L. 'Grasslands Apanui' cocksfoot became co-dominant. Cattle pastures also became more open than sheep pastures owing to a difference in the number of grass tillers which developed.

Scott (1977) has recently shown that one possible explanation for the differences reported by Monteath et al. was the differential return of plant nutrients, especially nitrogen, in the urine and faeces of the two types of animals.

Because of the conflict between Ruakura and Invermay results, the subject has received further attention at Invermay in experiments designed to measure the effects of grazing by the two different types of animals on pasture production. To this end, cattle and sheep have been compared within the same pasture management systems - i.e., both cattle and sheep pastures were allowed to grow to similar heights before grazing and were grazed to similar heights. Two such experiments are reported in this paper.

\section{EXPERIMENTAL}

In both experiments the pastures were sown to a mixture of Ruanui perennial ryegrass, Lolium (multiflorum $\times$ perenne) 'Grasslands Manawa' ryegrass, 'Grasslands Apanui' cocksfoot, Phleum pratense L. 'Grasslands Kahu' timothy, Trifolium repens L. 'Grasslands Huia' white clover, and Trifolium prafense L. 'Grasslands Turoa' red clover.

The stock used in the experiments were yearling Angus $\mathrm{X}$ Friesian cattle and Romney wether hoggets. Equivalent liveweights of cattle and sheep were applied per unit area at each grazing in both experiments.

Pasture DM production was measured by the Australian difference technique (Lynch; 1950). A two-tier sampling system, involving mowing to $2 \mathrm{~cm}$ and then sub-sampling the mown area to ground level, allowed all pasture measurements to be based on ground level as the datum. 


\section{EXPERIMENT 1}

The object of Experiment 1 was to measure the effects of changing the type of grazing animal upon pasture production and composition. The following four treatments were applied:

$\begin{array}{ccc}\text { Symbol } & \text { Previous Grazing } & \text { Present Grazing } \\ 1 \text { cc } & \text { Cattle } & \text { Cattle } \\ \mathbf{2} \text { cS } & \text { Cattle } & \text { Sheep } \\ \mathbf{3} \text { SC } & \text { Sheep } & \text { Cattle } \\ \mathbf{4} \text { sS } & \text { Sheep } & \text { Sheep }\end{array}$

There were four replicates of each treatment.

The pasture management was fixed -- pastures were grazed when they reached a mean height of $15 \mathrm{~cm}$ and animals were removed at a mean pasture height of $3 \mathrm{~cm}$, two to three days later. At times of slow growth, when height requirements were not met, the pastures were grazed at 6- to 8-week intervals. Experimental pastures were not grazed over the June-August period.

The experimental treatments were applied to a single cattle or sheep pasture typical of those reported by Monteath et al. (1977) . Since farmlet grazing was the "previous grazing" before the change in class of animal, the results of Experiment 1 are shown in association with farmlet results in Table 1 and Figs. 1 to 3. "Present grazing" refers to the class of animals grazing the pastures since 1972 in Experiment 1.

\section{EXPERIMENT 2}

In Experiment 2 the effects of grazing by either cattle or sheep on pasture production were compared under four different rotational grazing management systems for three years. Pastures were allowed to grow either to about $20 \mathrm{~cm}$ before grazing (long treatments), or to about $10 \mathrm{~cm}$ (short treatments). Animals were removed when the pasture was grazed either to a mean height of about $6 \mathrm{~cm}$ above ground level (lax grazing), or to about $3 \mathrm{~cm}$ (severe grazing), 2 to 3 days later. At times of slow growth, when height requirements were not reached, long pastures were grazed at intervals of up to $\mathbf{8}$ weeks. The pastures were not, grazed in the June-August period. The treatments were as follows: 
CATTLE AND SHEEP GRAZING

$\begin{array}{ccc}\text { Pasture Height } & \text { Grazing Severity } & \text { A nimals } \\ \text { Long } & \text { Lax } & \text { Cattle } \\ \text { Long } & \text { Lax } & \text { Sheep } \\ \text { Long } & \text { Severe } & \text { Cattle } \\ \text { Long } & \text { Severe } & \text { Sheep } \\ \text { Short } & \text { Lax } & \text { Cattle } \\ \text { Short } & \text { Las } & \text { Sheep } \\ \text { Short } & \text { Severe } & \text { Cattle } \\ \text { Short } & \text { Severe } & \text { Sheep }\end{array}$

There were two replicates of each treatment.

\section{RESULTS AND DISCUSSION}

\section{Change from Sheep to Catt'Le Grazing}

A change of pasture use from sheep grazing to cattle grazing reduced pasture production in three of the four years of the experiment (Table 1). A dramatic reduction in pasture production

TABLE 1: PASTURE PRODUCTION FROM CATTLE AND SHEEP PASTURES (kg DM/ha/yr)

\begin{tabular}{|c|c|c|}
\hline Y ear & Sheep & Cattle \\
\hline $1968-9$ & 8960a (102) & $8610 a(98)$ \\
\hline $1969-70$ & $14570 \mathrm{~A}(120)$ & $9640 \mathrm{~B}(80)$ \\
\hline 1970-1 & 12570 A (118) & 8740 B (82) \\
\hline $1971-2$ & $13680 \mathrm{~A}(107)$ & 11910 В (93) \\
\hline Mean ratic & & \\
\hline
\end{tabular}

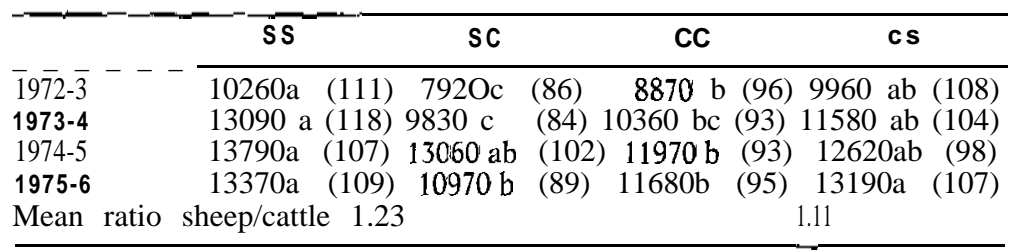

Notes: Duncan's notation applies within rows, means without a common letter differ significantly (lower case, $P<0.05$; upper case, $P<0.01$ ). 1968-72 Data from Monteath et al. (1977).

1972-76 Data from Experiment 1

Values in parentheses in this and following tables are the relative yields (mean yields of treatments in any year $=100$ ).

occurred in the first year after the change (1972-3). In contrast, Monteath ef al. (1976) and Joyce ( 1970) both reported that differences in production between cattle and sheep farmlet pastures developed after the first year. The reduction persisted in 1973-4 and 1975-6 but the change had little effect on pasture 
tomes D.M.

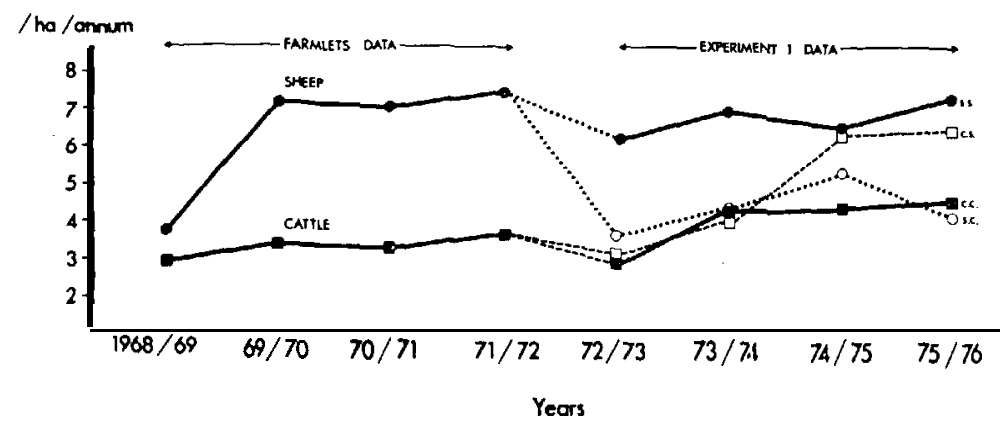

Fig. 1: Ryegrass production from pastures grazed by cattle or sheep.

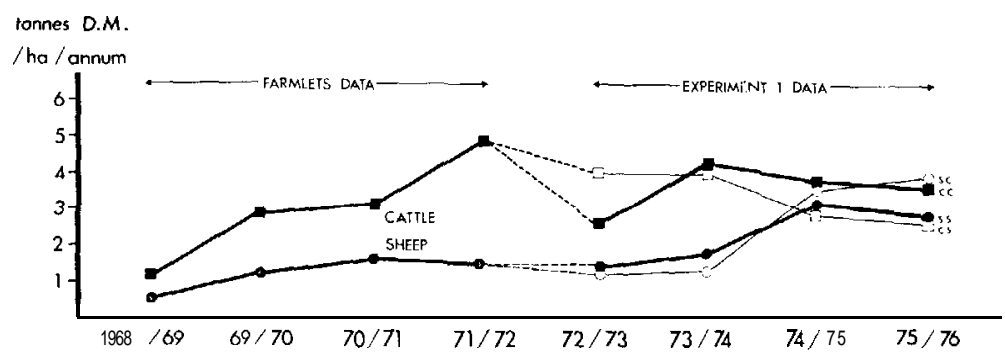

FIG. 2: Cocksfoot production from pastures grazed by cattle or sheep.

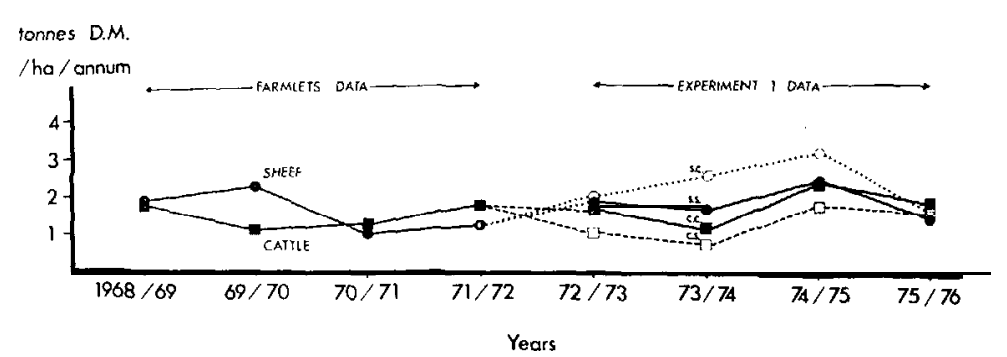

FIG. 3: White clover production from pastures grazed by cattle or sheep. 
production in the third year (1974-5). Differences in pasture production tended to occur during late summer and autumn when the pastures were often affected by a moisture stress. Thus pasture growth was poor at this time in 1972-3, but good in the third year.

Ryegrass production was reduced by the change to cattle grazing (SC). This occurred in the first year (Fig. 1) and the ryegrass component rapidly became similar to that under long-term cattle grazing (CC).

With the change to cattle grazing the proportion of cocksfoot increased each year and in 1975-6 cocskfoot production equalled ryegrass (Fig. 2). Monteath et al. similarly found that cocksfoot production increased in cattle farmlet pastures (Fig. 2). Summer production of white clover increased with the change to cattle grazing but there was litile eflect at other times of the year (Fig. 3).

\section{Change from Cattle to Sheep Grazing}

A change of pasture use from cattle to sheep grazing (CS) caused a gradual improvement in pasture production which reached significance in the fourth year of the experiment (Table 1). It is possible that the improvement could have been made more rapidly if an alternative management such as set-stocking the pasture with sheep over the spring-early summer (lambing to weaning) period, as is typical in Otago and Southland, was used.

The ryegrass component of the pasture did not increase compared with continued cattle grazing (CC) until the third year (Fig. 1). The proportion of cocksfoot declined steadily over the second and third years (Fig. 2) and production of white clover was consistently less in the pastures changed to sheep grazing (Fig. 3).

\section{grazing antmals and Pasture Pronuction}

In Experiment 1 previous grazing history had little effect on the subsequent annual pasture production. The important effect was that of the present grazing animals. Thus in Experiment 1 pastures grazed by sheep produced on average 16\% more DM each year than those grazed by cattle (Table 2), irrespective of the previous grazing. Although changes in pasture production occurred less rapidly in Experiment 2 (Table 3), sheep pastures consistently produced more DM than cattle pastures over a range of managements (Table 4). In this experiment differences be- 
TABLE 2: EFFECT OF PRESENT GRAZING ANIMALS ON PASTURE PRODUCTION - EXPERIMENT 1 ( $\mathrm{kg} D M / h a / y r)$

\begin{tabular}{|c|c|c|}
\hline & Sheep (mean of $S S+C S$ ) & Cattle (mean of $\mathrm{CC}+\mathrm{SC}$ ) \\
\hline $1972-3$ & 10110 A (109) & 8390B (91) \\
\hline $1973-4$ & 12330 A (110) & 10090 B (90) \\
\hline $1974-5$ & 13200.a (103) & $12510 \mathrm{a}(97)$ \\
\hline $1975-6$ & 13330 A (108) & 11330 В (92) \\
\hline \multicolumn{2}{|c|}{ Mean ratio sheep/cattle } & 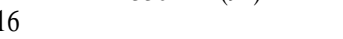 \\
\hline
\end{tabular}

Note: Duncan's notation applies within rows.

I'ABLE 3: MAIN EFFECT OF GRAZING ANIMALS ON PASTURE PRODUCTION - EXPERIMENT 2 ( $k g D M / h a / y r)$

\begin{tabular}{|c|c|c|c|}
\hline Animals & $1972-3$ & $1973-4$ & $1974-5$ \\
\hline Cattle & 8920 a (95) & 10690 a (96) & 10320 b (91) \\
\hline Sheep & 9900 a (105) & 11490 a (104) & 12370 a (109) \\
\hline Ratio sheep/cattle & 1.11 & 1.18 & 1.20 \\
\hline
\end{tabular}

Notes: Duncan's notation applies within columns. SED within columns $=749$.

TABLE 4: ANNUAL PASTURE PRODUCTION

EXPERIMENT 2 ( $\mathrm{kg} D M / \mathrm{ha})$

\begin{tabular}{|c|c|c|c|}
\hline Management & Cattle & Sheep & Ratiò Sheep/Cattle \\
\hline Long lax & $10150(93)$ & $11660(107)$ & 1.15 \\
\hline Long severe & 10900 (94) & $12330(106)$ & 1.13 \\
\hline Short lax & $9490 \quad(95)$ & $10400(105)$ & 1.10 \\
\hline severe & $9370(94)$ & $10630(106)$ & 1.13 \\
\hline
\end{tabular}

Notes: Means of 3 years.

SED within rows $=865$.

TABLE 5: MAIN EFFECT OF GRAZING ANIMALS ON RYEGRASS PRODUCTION - EXPERIMENT 2

( $k g D M / h a / y r)$

\begin{tabular}{lccc}
\hline Animals & \multicolumn{1}{c}{$1972-3$} & 1 1'9734 & \multicolumn{2}{c}{$1974-5$} \\
\hline Cattle & 4680 a $(93)$ & $5710 \mathrm{a}(90)$ & $5150 \mathrm{~b}$ (84) \\
Sheep & 5360 a (107) & $6950 \mathrm{a}(110)$ & 7170 a (116) \\
Ratio sheep/cattle & 1.15 & 1.22 & 1.38 \\
\hline
\end{tabular}

Notes: Duncan's notation applies within columns. SED within columns $=804$ 
tween the effects of grazing animals were not significant until the third year when sheep pastures produced about $20 \%$ more DM than cattle pastures (Table 3). Almost all of these differences can be accounted for by the decline in ryegrass production from pastures grazed by cattle relative to those grazed by sheep (Table 5),

\section{Grazing Animals And pasture Composition}

In three different experiments at lnvermay there has been a consistent effect of cattle grazing on the mixed grass/clover pastures. Cattle grazing has reduced the production of ryegrass in farmlet pastures (Monteath et al. (1977) and in Experiment 1 where cattle replaced sheep grazing. In Experiment 2 ryegrass production on cattle pastures was lower than on sheep pastures under a range of different managements. Some of the decreased ryegrass production has been offset by increased cocksfoot production under cattle grazing. This occurred in Experiment 1, and has been reported by Monteath et al. (1977), and by Taylor (1975), although it was not apparent in Experiment 2. At Ruakura it appears that under cattle grazing, paspalum (Paspalum dilafafum) may replace ryegrass to some extent (Parker, 1970) in a way simiiar to that of cocksfoot at Invermay.

The importance of dry summer-autumn periods on pasture production under cattle and sheep grazing has already been stressed. Suckling (1975) found that hill pasture, closely grazed by sheep, was highly sensitive to even short periods of drought and in dry summers lost much of its ryegrass and clover. The same principles apply to cattle grazing. In the experiments reported a proportion of the area within cattle pastures was very closely grazed. The proportion was greater in treatments grazed to $3 \mathrm{~cm}$ than those grazed to $6 \mathrm{~cm}$. It was from such areas that ryegrass declined most rapidly, and the effect was particularly noticeable in dry seasons. Weeda and During (1974) have shown that even under summer irrigation perennial ryegrass disappeared from pasture under cattle grazing.

Monteath et al. (1977) have suggested three possible reasons for the decline in ryegrass under cattle grazing:

(1) The different defoliation regimes used on cattle and sheep farmlets.

(2) The uneven return of plant nutrients to pasture by cattle compared with sheep. 
(3) Increased soil compaction by cattle favouring more drought resistant plant species.

The experiments reported in this paper suggest that the animals themselves have important effects on pasture composition, independent of differences in pasture management. Scott (1977) has demonstrated that differential nitrogen returns to cattle and sheep pastures affected DM production. There is no proof that this directly affected botanical composition, although perennial ryegrass is recognized as a high fertility demanding species. It appears that when nutrients are collected from the complete area of a pasture and returned to only a small proportion of the area, as in cattle grazing, the areas where there is a nil return lose fertility and become less favourable for ryegrass growth. This decline in fertility is likely to be greatest towards the end of the grazing season when dry conditions put ryegrass under further stress.

Monteath et al. (1977) showed that the population of ryegrass tillers per unit area of pasture was greater under sheep grazing than in cattle pastures. This was confirmed in Experiment 1. Recent preliminary studies at Tnvermay in collaboration with Dr I. Hall may offer a further explanation of both the tiller populations and composition differences between cattle and sheep pastures. These have shown that, although physical uprooting of ryegrass tillers is apparent even in sheep pastures at dry periods, the incidence of the uprooting was far higher under cattle grazing than sheep. This is probably a consequence of the more violent pulling action typical of cattle grazing compared with the bite and pull action of grazing sheep. Perennial ryegrass has a high leaf strength (Evans, 1964) and under cattle grazing the breaking point of the ryegrass plant tissue is frequently at root level. Thus whole tillers are removed, especially young tillers at the periphery of plants. Cocksfoot leaves are more easily broken when pulled by cattle and long leaves require a number of bites to be grazed close to the crown. This, along with the persistence of the tillers, may explain why cocksfoot has thrived under cattle grazing.

It appears that perennial ryegrass may not be the most suitable pasture species for pastures grazed solely by cattle. Species with a low leaf strength or a good resistance to uprooting may be better suited to cattle grazing. However, since cattle and sheep are both carried in most grazing enterprises, sheep can be used to modify the effect of the cattle on pastures. The experiments show that, if cattle and sheep are to be run on separate areas, the cattle blocks should be alternated with sheep at least annually. 
If they are alternated more regularly a measure of internal parasite control can be obtained (Southcott and Barger, 1975). The double benefit of reduced parasites and improved pastures can be obtained if pastures are spelled from cattle grazing in either spring or autumn when ryegrass tillering is greatest. An alternative system of grazing both cattle and sheep together could possibly maintain highly productive pastures equally well.

\section{ACKNOWLEDGEMENTS}

A. J. M. Crawford, L. J. Cranshaw, J. G. Grant, and R. W. A. Ehelepola, and the staff of the Botanical Services Laboratory at lnvermay for valuable technical assistance, and P. D. Johnstone for statistical analyses.

\section{REFERENCES}

Evans, P. S., 1964. N.Z. $/ l$ agric. Res., 7: 508-13.

Joyce, J. P., 1970. Proc. N.Z. Grassid Ass., 32: 168-80.

Lynch, P. G., 1960. N.Z. Dep. Agric. Bull.' 399: 74.

Monteath. M. A., 1970. Proc. N.Z. Grassld Ass., 32: 181-90.

Monteath, M. A.; Johnstone, P. D.: Boswell, C. C.. 1977. N.Z, // agric. Res., 20 (in press).

Parker, 0. F., 1970. Proc. Ruakura Fmrs' Conf.: 204-5.

Scott, R. S., 1977. N.Z. $l l$ agric. Res., 20 (in press).

Southcott, W. H.; Barger, I. A., 1975. Proc. World Conf. Anim. Prod., 3: 246-50.

Suckling, F. E. T., 1975. N.Z. /l exp. Agric., 3; 351-436.

Taylor, A. G., 1975. Proc. N.Z. Grassld Ass., 37: 104-13.

Weeda, W. C.; During. C., 1974. Proc. N.Z. Grassld Ass., 36: 54-61. 